\title{
FACTORS INFLUENCING MOTIVATION IN LEARNING ENGLISH OF MANGUSADA BADUNG GENERAL HOSPITAL STAFF
}

\author{
Ketut Santi Indriani
}

Faculty of Arts, Udayana University, Jl. Raya Kampus Unud, Jimbaran, Badung, Bali 80361, Indonesia

\section{ARTICLE INFO}

Keywords:

English learning

Influencing factors

Motivation

Article History:

Received: $19 / 01 / 2020$

Accepted: 31/05/2020

Available Online:

31/05/2020

\begin{abstract}
English as a means of communication is used in many fields, such as health, economic, etc. This research was conducted at Mangusada Badung General Hospital located in the Badung regency of Bali Province. Mangusada Badung General Hospital has a high frequency of giving health services to foreign tourists. The ability to communicate in English is not only needed by medical personnel who are directly serve the foreign patients but also needed by other hospital staff, such as public relations staff, telephone operators, non-medical laboratory staff, registration staff, and others. This research is aimed to identify the influencing factors of motivation in learning English of Mangusada Badung General Hospital staff. The data in this research were collected through a questionnaire method with closed questions which were distributed to 50 respondents of staff from various divisions at Mangusada Badung General Hospital. The data obtained were analyzed using the motivation theory delivered by Gardner, William $\mathcal{E}$ Burden, and Finocchiaro. From the research, it is found that the five categories of influencing factors of motivation (personality, behavior, the role of teacher, learning style, and language relation) have almost the same portion in influencing the motivation in learning English.
\end{abstract}

2442-305X / (C) 2020 The Author, this is open access article under the (CC-BY-NC) license (https://creativecommons.org/licenses/by-nc/4.0/), DOI:10.19105/ojbs.v14i1.2972

\footnotetext{
${ }^{*}$ Corresponding Author:

Email address: kt.santi.indriani@gmail.com (K. S. Indriani)
}

\section{A. Introduction}

Badung is one of the districts which has the highest level of tourism activity compared to other districts in Bali Province. Based on data obtained on the website of the Central Bureau of Statistics of the Province of Bali, the number of starrated hotels throughout the Province of Bali in 2017 was 551 with 443 of them located in Badung Regency. This is supported by the number of attractions found in the Badung Regency. Considering that tourism activities in Badung Regency are very high, the community's need for foreign language skills especially in English is also very high both in the fields that are directly or indirectly related to tourism, one of which is in the health sector. Workers in the field of health services in the form of clinics, 
health centers, and hospitals also need English language skills to provide optimal health services for tourists especially in Badung Regency.

Mangusada Badung Hospital is one of the government health service centers in the Badung Regency. Mangusada Badung General Hospital has a high frequency of serving health for foreign tourists. The ability to speak English is not only needed by medical staff who deal directly with foreign patients but also needed by other staff. English language skills possessed by every staff in the Mangusada Badung General Hospital are certainly not the same. This is greatly influenced by their motivation in learning English.

Williams and Burden stated that motivation is a cognitive and emotional state that arises in a person and lead to conscious decision making to act and sustainably provide physical and intellectual efforts. ${ }^{1}$ Motivation is also defined as an internal process that cannot be directly observed but can activate, guide, and maintain the continuity of a habit that can be seen clearly. ${ }^{2}$ Motivation in the language learning process is defined as the level of effort of a person to learn a language that arises from the desire to learn the language and the desire to get from the process of learning the language. ${ }^{3}$ The most important part of

1 Marion Williams and Robert L. Burden, Psychology for Language Teachers: A Social Constructivist Approach (Cambridge: Cambridge University Press, 1997), 170.

2 Robert A. Baron, Psychology (New Delhi: Prentice-Hall of India, 1996), 23.

${ }^{3}$ Chunmei Long, Zhu Ming, and Liping Chen, "The Study of Student Motivation on English Learning in
English learning is motivating students to heighten the teaching effect. Thus, someone who is motivated in learning a language is someone who is very eager to learn, is eager to increase the effort in his learning activities, is eager to maintain the continuity of learning activities. ${ }^{4}$ Several factors influence the motivation in language learning, those are learner's personality, learner's attitudes, the role of the teacher, learning style, and the relation between languages.

A person's personality (extrovert, introvert, confident, active, passive, independent, shy, etc.) influences the motivation in learning English. A confident, extrovert, and active personality will tend to succeed in achieving goals in learning English.

In vice versa, lack of confidence, introvert, and passive personality will tend to fail to reach the goals of learning English. The results of data analysis in a study conducted by Zafar et al. show that students with extroverted personalities managed to get better scores compared to introverted students. This also happens in terms of language proficiency. ${ }^{5}$ The term helplessness appears in the process

\footnotetext{
Junior Middle School - A Case Study of No. 5 Middle School in Gejiu," English Language Teaching 6, no. 9 (August 14, 2013): 136-45, https://doi.org/10.5539/elt.v6n9p136.

4 Robert C. Gardner, Social Psychology and Second Language Learning: The Role of Attitudes and Motivation (London: E. Arnold, 1985), 10.

${ }^{5}$ Shahila Zafar, Z. A. Khan, and K. Meenakshi, "Extraversion-Introversion Tendencies and Their Relationship with ESL Proficiency: A Study of Chinese Students in Vellore, India," Pertanika: Journal of Social Science and Humanities 25, no. 2 (February 2017): 687-703.
} 
of learning English. ${ }^{6}$ This term is conveyed by William and Burden. They define helplessness in the learning process as a condition in which someone feels that failure in the learning process is due to the lack of intelligence and there is nothing he can do about it.

Learner's attitudes also greatly influence motivation in learning English. If someone has a positive attitude in learning English, the learning objectives will be achieved optimally. This positive attitude can be defined as being attentive when studying, serious in doing the task, or having a desire to get better results.

The role of the teacher is one of the factors that also influences a person's motivation in learning English. ${ }^{6}$ Finocchiaro states that there are several teacher roles that can greatly influence student's motivation in learning English. ${ }^{7}$ The role is to ensure that students understand each dialogue, situation, the essence of a discourse, give extensive assignments, examine the student's work with full responsibility by giving feedback for students, provide opportunities for students to assess their own work or their friends' work, being sensitive on the difficulties experienced by students in the learning process and provide rewards for small successes achieved by students. The most important thing related to the teacher's role is teacher's English proficiency, pedagogical knowledge, and

\footnotetext{
${ }^{6}$ Williams and Burden, Psychology for Language Teachers, 100.

7 Mary Finacchiaro, "Reflections on the Past, the Present, and the Future," in A Forum Anthology: Selected Articles from the English Teaching Forum 1979-1983, 1979, 22-23.
}

socio-affective skills. Teachers who do not possess those skills will frequently find difficulties in teaching then it will be very difficult to build students' English proficiency. ${ }^{8}$

In addition to several factors that have been mentioned, learning styles also affect one's motivation in learning English. If someone is given the freedom to choose a learning style that suits their passion, then the tendency to succeed in learning English will be achieved.

Relationships between languages also influence motivation to learn English. ${ }^{9}$ If a language is considered to provide more benefits, then someone will tend to be motivated to learn the language. For example, in Rome, students and parents are faced with the opportunity to choose English or French to study at school. In general, they will choose English because it has become a lingua franca that allows someone to get a better job when compared with French.

To be an international standard hospital, Mangusada Badung Regional Hospital hopes that all hospital staff will be able to communicate well in English. However, the ability of Mangusada Badung Regional Hospital staff to communicate using English is not the same. This is influenced by the motivation

\footnotetext{
8 Bogor Lumbanraja and Lino Reynoso, "English Teachers' Effectiveness and Students' English Proficiency at Selected Colleges in Dili, East Timor: Input for Enhancement Programs," English Language Teaching 12, no. 10 (September 26, 2019): 96-107, https://doi.org/10.5539/elt.v12n10p96.

${ }^{9}$ Abrudan Caciora Simona Veronica, "Motivation in Language Learning," Annals of the University of Oradea, Economic Science Series 17, no. 1 (2008): 561.
} 
of Mangusada Badung Regional Hospital staff in learning English.

Motivation, especially in learning English can be influenced by several factors, namely one's personality, one's attitude, teacher's role, one's learning style, and the relationship between languages. ${ }^{10}$

Someone's motivation is very much influenced by self-efficacy. Self-efficacy is a person's confidence in his ability to do something and achieve goals. ${ }^{11} \mathrm{~A}$ person's personality can affect his motivation in learning English. Someone who is not successful in the language learning process generally shows a personality that lacks confidence, is shy, afraid to express his opinion, and tends to be often nervous. The role of the instructor greatly affects the motivation of students in participating in teaching and learning activities. Teacher's creativity has a great influence on the student's success in learning a language. A teacher who is able to manage classrooms with active and interesting activities and is able to transfer materials properly will motivate students to achieve learning goals. However, teacher's behavior in vise versa can demotivate students in learning English, such as unpunctuality, disrespect, or harsh behavior. ${ }^{12}$

10 Febi Nur Biduri, 'The Effect of Teacher's Creativity on Native Indonesian Students' Success in Learning Chinese Language', OKARA: Jurnal Bahasa dan Sastra 11, no. 2 (2017): 251, https://doi.org/10.19105/ojbs.v11i2.1492.

11 James Life, "Motivation and EFL University Students in North-East Asia," Asian EFL Journal 13, no. 3 (September 2011): 11-41.

12 Maheen Ali and Zahid Pathan, "Exploring Factors Causing Demotivation and Motivation in Learning English Language among College Students of
What also affects one's motivation to learn English is the person's learning style. If teaching and learning activities in English are in accordance with his learning style or it is possible for him to learn English in accordance with his learning style, then the opportunity to achieve learning objectives will be larger and vice versa. Another important factor that can influence motivation to learn, especially English is the relationship between languages. If English is considered to have a strong relationship with its practical needs, then someone will be motivated to learn the language.

Some research has been studied on this topic. Research entitled the Impact of Motivation on English Language Learning conducted by Mitra Alizadeh aims to determine the motivational conditions and key motivational factor in learning English. ${ }^{13}$ The results of this study show that learners' motivation can go up and down depending on the context of language learning and the key factor that determines motivation in learning English is the teacher's role. The ability of teachers to motivate students to learn English will greatly affect the success of the learning process.

Ahmad and Yusuf conducted research to find the motivational factors in learning English in Aceh. ${ }^{14}$ The result

Quetta, Pakistan," International Journal of English Linguistics 7, no. 2 (January 20, 2017): 81-89, https://doi.org/10.5539/ijel.v7n2p81.

13 Mitra Alizadeh, "The Impact of Motivation on English Language Learning," International Journal of Research in English Education 1, no. 1 (2016): 11-15.

14 Diana Achmad and Yunisrina Qismullah Yusuf, "Exploring The Motivational Factors For Learning English In Aceh," Dirasat: Human and Social 
shows that the factor that influences motivation to learn English in Aceh is awareness of the importance of English as an international language that will facilitate them to communicate and deal with foreigners who come from English speaker countries.

Other research related to the topic in this study is research conducted by Rahman et. al. ${ }^{15}$ This study aims to determine the factors that influence motivation in learning a second language. The result indicates that the factors which influence motivation in learning a second language are teachers' influence, personal attitude, and parental influence.

The difference between those researches with this research is that this research is aimed at identifying the influencing factors of motivation in learning English of Mangusada General Hospital staff. In contrast to the researches mentioned above, this research focuses on English learning. Besides this research not only reviews the factors that influence motivation in learning English in terms of teachers' role, students' attitude, and parents' influences but also in terms of language relations and environmental factors.

\section{B. Method}

This research is a field research ${ }^{16}$ conducted at the Mangusada Badung

Sciences 43, no. 5 (2016): 2223-34, https://doi.org/10.35516/0272-043-993-015.

15 Hamidah Abdul Rahman et al., "Factors Affecting Motivation in Language Learning," International Journal of Information and Education Technology 7 , no. 7 (July 2017): 543-47.

${ }^{16}$ Moh. Nazir, Metode Penelitian (Jakarta: Ghalia Indonesia, 2005), 65.
General Hospital located on Jalan Raya Kapal, Mangupura, Mengwi, Badung Regency, Bali-80351. This research used a descriptive quantitative approach. ${ }^{17}$ The data population in this research was the staff of Mangusada Badung General Hospital with a sample of 50 people who came from various units, namely the medical staff, nursing staff, non-nursing staff, medical, and non-medical administration staff.

The data collection method in this research applied a questionnaire technique. Respondents were asked to choose answers to the questions on the questionnaire by choosing a score of 1 to 5 using the Likert's scale assessment. ${ }^{18}$ This research uses a quantitative descriptive analysis method because this research describes the results of analyzing data in the form of numbers or qualitative data related to the factors that influence the motivation of Mangusada Badung General Hospital staff in learning English. The calculation of each type of factor that influences the motivation in learning English owned by each respondent is done by averaging the scores given on each question.

\section{Results}

Motivation is a driving factor that determines the success of the learning process. Knowing students' motivation in learning English will be very helpful in determining activities during learning.

\footnotetext{
17 Sugiyono, Metode Penelitian Bisnis (Bandung: Pusat Bahasa Depdiknas, 2003), 14.

${ }^{18}$ Rensis Likert, A Technique for the Measurement of Attitudes (New York: New York University, 1932), $1-55$.
} 
Interesting activities will increase student motivation in learning English. ${ }^{19}$

Of the 50 respondents in this research, these factors were found that influenced the motivation of Mangusada Badung Regional Hospital staff in learning English. The magnitude of the influence of these factors on the emergence of Mangusada Badung Regional Hospital workforce motivation in learning English will be discussed in more detail as follows.

Table 1 . below shows the influencing factors in learning English possessed by the staff of RSUD Mangusada Badung. Learner's personality and learner's attitude factors have the same average value of 3.39 and the relation between languages factor has an average value of 3.21. These three factors are categorized as factors that are quite influential on the motivation of Mangusada Badung Regional Hospital staff in learning English.

Table 1.

The Average Values of Motivation Influencing Factors in Learning English of RSUD Mangusada Staff

\begin{tabular}{ll}
\hline $\begin{array}{l}\text { Influencing Factors of } \\
\text { Motivation in Learning } \\
\text { English }\end{array}$ & $\begin{array}{l}\text { Average } \\
\text { Values }\end{array}$ \\
\hline Learner's personality & 3.39 \\
Learner's attitudes & 3.39 \\
The role of the teacher & 3.51 \\
Learning style & 3.62 \\
The relation between languages & 3.21 \\
\hline
\end{tabular}

19 Ratanawalee Wimolmas, "A Survey Study of Motivation in English Language Learning of FirstYear Undergraduate Students at Sirindhorn International Institute of Technology (SIIT), Thammasat University," in The 2nd FLLT Conference, vol. 4, 2013, 904-15.
Although not classified as very influential factors, the emergence of these three factors cannot be ignored. Two other factors that influence the motivation of RSUD Mangusada staff in learning English are the role of the teacher and the learning style. Based on the analysis of the data, it is found that these two factors have a high average value which is categorized as very influential based on the Likert scale.

The role of the teacher has an average value of 3.51 . It means that teacher plays an important role in increasing students' motivation in learning English. The teacher can influence students' academic abilities if the teacher is able to encourage, motivate, and inspire students. Conversely, teachers who do not play this role will provide a bad experience for students in learning activities. These bad experiences will lead to negative feelings towards the learning process that will affect student success. ${ }^{20}$ In addition, the teacher's attitude toward the language that he teaches can influence students. If he has a positive attitude then he can be a model for students to communicate. This will affect students' academic progress. ${ }^{21}$

As it is already mentioned above, Finocchiaro stated that there are some

${ }^{20}$ Olaniyan-Shobowale K.O. and Arimiyau Olanike
Sekinat, "Qualities of an Ideal Language Teacher: A
Gender-Based Investigation," English Language
Teaching and Linguistics Studies 1, no. 1 (May 7,
2019):
2640-9844,
https://doi.org/10.22158/eltls.v1n1p40.
${ }^{21}$ Salwa Al Darwish, "Teachers' Attitude Toward a
Foreign Language: Factors Affecting the Target
Language Teaching Process," International Journal
of English Language Teaching 5, no. 1 (2018): 1-8,
https://doi.org/10.5430/ijelt.v5n1p1. 
important roles of the teacher in English language learning, those are a) ensuring that students understand every dialogue, situation, and essence of a discourse; b) provide extensive training in using alternatives both verbal and non-verbal language for communicative expression, language structure, and language elements; c) correct important mistakes wisely by paraphrasing questions, expanding answers, or by clearly giving answers; d) allow students to self-assess their work or do it with their friends; e) shows attention to the problems that occur in the environment where learning takes place or to the problems experienced by students individually; and f) allows students to feel small successes through progress towards the success of the language learning process. ${ }^{22}$ This means that teacher should be well prepared and well organized in running the class. The teacher will a teacher's readiness will greatly affect students' motivation in attending classes. Teachers must set a high expectation of achieving learning outcomes because if the teacher sets low expectations, then students will do below those expectations. ${ }^{23}$

Learning style is the influential factor of motivation in learning English which has the highest average value of 3.62 . Learning style is the preferred way for learners to accept and absorb the material

22 Finacchiaro, "Reflections on the Past, the Present, and the Future," 22-23.

${ }^{23}$ Dat Bao, Hassan Abdilah, and Raqib Chowdhury, "EFL Learners Moving to an ESL Context: Motivating and Demotivating Factors in English Language Learning among Iraqis," The New English Teacher 6, no. 1 (January 1, 2012): 12544. provided. Each student has a different learning style. This learning style will greatly affect their success in learning English. If they get the opportunity to learn by applying the learning styles they like, then they will be able to receive and absorb the material provided properly.

Good learning activities are learning that gives the impression to students that they are learning of their own volition, in a way that is determined independently and effectively. ${ }^{24}$ Opportunities to learn according to the preferred learning style will be largely determined by the opportunities given in class. Indeed, the opportunity to apply the preferred learning style is determined by the teacher's role. It would be very useful if a teacher knows the learning style that is liked by his students. Thus the teacher will be able to prepare the class so as far as possible can be run according to the learning style preferred by students. A teacher must realize that he is the most important agent in a language learning process. Therefore, the teaching style must be highly considered to adjust learning activities following student learning styles. ${ }^{25}$

Based on the results of data analysis it was also found that there are two learning styles which mostly preferred by students; visual and kinesthetic learning styles. Visual learning style is a

\footnotetext{
24 Martin Lamb, "The Motivational Dimension of Language Teaching," Language Teaching 50, no. 3 (July 2017): 301-46, https://doi.org/10.1017/S0261444817000088.

25 Ayfer Su Bergil and Ayşegül Erçevik, "The Prospective EFL Teachers' Impressions towards Teaching Styles: Foresights for Their Professions," Journal of Language and Linguistic Studies 15, no. 4 (December 30, 2019): 1236-51, https://doi.org/10.17263/jlls.668394.
} 
learning style that emphasizes the use of images. Meanwhile, the kinesthetic learning style is a learning style that involves physical activity in the learning process. By knowing the learning styles preferred by students, the teacher can design activities in the class during the learning process. For example, the teacher can use pictures to stimulate students to talk to. Other things can also be done such as inviting students to work in pairs or groups that can provide an opportunity for students' mobilization. ${ }^{26}$ Students who have adequate motivation will become efficient language learners with the best language skills.

\section{Conclusion}

Motivation is an inseparable part of the English learning process. Motivation will greatly affect a student's success in achieving learning goals. If a student has a high motivation in learning, then he will tend to succeed in achieving learning goals. Vice versa, low motivation will make it difficult for the student to achieve learning goals. Motivation can be influenced by several factors, those are learner's personality, learner's attitude, the role of the teacher, learning style, and the relationship between languages. Based on the results of data analysis, it was found that these five factors influence the motivation of Mangusada Hospital staff in learning English. The most influential

${ }^{26}$ I Wayan Suryasa, I Prayoga, and I Werdistira, "An Analysis of Students' Motivation Toward English Learning As Second Language Among Students In Pritchard English Academy (PEACE)," International Journal of Social Sciences and Humanities (IJSSH) 1 (August 30, 2017): 43-50, https://doi.org/10.21744/ijssh.v1i2.36. factors are the teacher's role and learning style. Both of these factors have a relationship with one another. The student will tend to be motivated in learning English if he is allowed to apply the preferred learning style in the learning process. The opportunity to apply the preferred learning style is very much determined by the teacher's role. Teachers must know the learning styles that students like so that they can create a pleasant learning environment for them. If the teacher already knows the learning style that is liked by students, he will prepare the class so that he can apply the learning style that students.

\section{References}

Achmad, Diana, and Yunisrina Qismullah Yusuf. "Exploring the Motivational Factors for Learning English in Aceh." Dirasat: Human and Social Sciences 43, no. 5 (2016): 2223-34. https://doi.org/10.35516/0272-043993-015.

Ali, Maheen, and Zahid Pathan. "Exploring Factors Causing Demotivation and Motivation in Learning English Language among College Students of Quetta, Pakistan." International Journal of English Linguistics 7, no. 2 (January 20, 2017): 81-89. https://doi.org/10.5539/ijel.v7n2p81.

Alizadeh, Mitra. "The Impact of Motivation on English Language Learning." International Journal of Research in English Education 1, no. 1 (2016): 11-15.

Bao, Dat, Hassan Abdilah, and Raqib Chowdhury. "EFL Learners Moving to an ESL Context: Motivating and Demotivating Factors in English Language Learning among Iraqis." The New English Teacher 6, no. 1 (January 1, 2012): 125-44. 
Baron, Robert A. Psychology. New Delhi: Prentice-Hall of India, 1996.

Bergil, Ayfer Su, and Ayşegül Erçevik. "The Prospective EFL Teachers' Impressions towards Teaching Styles: Foresights for Their Professions." Journal of Language and Linguistic Studies 15, no. 4 (December 30, 2019): 1236-51. https://doi.org/10.17263/jlls.668394.

Biduri, Febi Nur. "The Effect of Teacher's Creativity on Native Indonesian Students' Success in Learning Chinese Language." OKARA: Jurnal Bahasa dan Sastra 11, no. 2 (2017): 243-52.

https://doi.org/10.19105/ojbs.v11i2.1 492.

Darwish, Salwa Al. "Teachers' Attitude Toward a Foreign Language: Factors Affecting the Target Language Teaching Process." International Journal of English Language Teaching 5, no. 1 (2018): 1-8.

https://doi.org/10.5430/ijelt.v5n1p1.

Finacchiaro, Mary. "Reflections on the Past, the Present, and the Future." In A Forum Anthology: Selected Articles from the English Teaching Forum 1979-1983, 19-30, 1979.

Gardner, Robert C. Social Psychology and Second Language Learning: The Role of Attitudes and Motivation. London: E. Arnold, 1985.

K.O., Olaniyan-Shobowale, and Arimiyau Olanike Sekinat. "Qualities of an Ideal Language Teacher: A GenderBased Investigation." English Language Teaching and Linguistics Studies 1, no. 1 (May 7, 2019): 2640-9844.

https://doi.org/10.22158/eltls.v1n1p4 0 .

Lamb, Martin. "The Motivational Dimension of Language Teaching." Language Teaching 50, no. 3 (July 2017): 301-46. https://doi.org/10.1017/S026144481 7000088 .
Life, James. "Motivation and EFL University Students in North-East Asia." Asian EFL Journal 13, no. 3 (September 2011): 11-41.

Likert, Rensis. A Technique for the Measurement of Attitudes. New York: New York University, 1932.

Long, Chunmei, Zhu Ming, and Liping Chen. "The Study of Student Motivation on English Learning in Junior Middle School - A Case Study of No. 5 Middle School in Gejiu." English Language Teaching 6, no. 9 (August 14, 2013): 136-45. https://doi.org/10.5539/elt.v6n9p136.

Lumbanraja, Bogor, and Lino Reynoso. "English Teachers' Effectiveness and Students' English Proficiency at Selected Colleges in Dili, East Timor: Input for Enhancement Programs." English Language Teaching 12, no. 10 (September 26, 2019): 96-107. https://doi.org/10.5539/elt.v12n10p9 6.

Nazir, Moh. Metode Penelitian. Jakarta: Ghalia Indonesia, 2005.

Rahman, Hamidah Abdul, Azizah Rajab, Shah Rollah Abdul Wahab, Faziah Mohd Nor, Wan Zarina Wan Zakaria, and Mohd Asyraf Badli. "Factors Affecting Motivation in Language Learning." International Journal of Information and Education Technology 7, no. 7 (July 2017): 543-47.

Sugiyono. Metode Penelitian Bisnis. Bandung: Pusat Bahasa Depdiknas, 2003.

Suryasa, I Wayan, I Prayoga, and I Werdistira. "An Analysis of Students' Motivation Toward English Learning As Second Language Among Students In Pritchard English Academy (PEACE)." International Journal of Social Sciences and Humanities (IJSSH) 1 (August 30, 2017):

43. https://doi.org/10.21744/ijssh.v1i2.3 6. 
Veronica, Abrudan Caciora Simona. "Motivation in Language Learning." Annals of the University of Oradea, Economic Science Series 17, no. 1 (2008): 557-62.

Williams, Marion, and Robert L. Burden. Psychology for Language Teachers: A Social Constructivist Approach. Cambridge: Cambridge University Press, 1997.

Wimolmas, Ratanawalee. "A Survey Study of Motivation in English Language Learning of First Year Undergraduate Students at Sirindhorn International Institute of Technology (SIIT), Thammasat University." In The 2nd FLLT Conference, 4:904-15, 2013.

Zafar, Shahila, Z. A. Khan, and K. Meenakshi. "ExtraversionIntroversion Tendencies and Their Relationship with ESL Proficiency: A Study of Chinese Students in Vellore, India." Pertanika: Journal of Social Science and Humanities 25, no. 2 (February 2017): 687-703. 